\title{
EMPIRICAL INFLUENCE OF ENVIRONMENTAL MANAGEMENT ON INNOVATION: \\ EVIDENCE FROM EUROPE
}

Marcus Wagner, Bureau d'Economie Théorique et Appliquée, Université Louis Pasteur, 61 avenue de la Fôret Noire, 67085 Strasbourg Cedex, E-mail: wagner@ cournot.u-strasbg.fr, Fax: +33 390242071

\begin{abstract}
This paper analyses the hypothesis that environmental management systems (EMS) and managerial activities to reduce negative environmental impacts which are not part of EMS have a positive influence on the probability of firms to carry out environmental innovations. Based on binary and multinomial discrete choice models, the relationship of a number of determinants on the occurrence of environmental innovations is studied using data collected during the "European Business Environment Barometer 2001/2002“ survey in 9 European states. The study finds that environmental management systems are associated with process innovations. However, the study did not find that environmental management systems are associated with product innovations. For product innovations, mainly information of consumers and eco-labelling activities show a positive association. Market research on the potential of environmental innovations positively relates to both process and product innovations. Importantly, firm size is not found to have any effect on the probability of a firm carrying out environmental product or process innovations.
\end{abstract}

Keywords: environmental, innovation, management systems, labelling, market research, marketing

appeared in:

Wagner, M. (2008). Empirical influence of environmental management on innovation: Evidence from Europe. Ecological Economics, 66(2-3), 392-402. 


\section{INTRODUCTION}

This paper tests whether environmental management systems and managerial activities to reduce negative environmental impacts that are not part of EMS have a positive influence on the probability of firms to carry out environmentally-friendly innovations, short environmental innovations. In order to avoid a common issue with empirical studies, namely their limited comparability, care was taken to ensure as much as possible comparability with previous studies. Furthermore, in order to overcome at least some of the limitations of earlier studies, the empirical analyses used to test the hypotheses developed in this paper are based on a questionnaire specifically targeted towards environmental management and innovation aspects which collects data at the firm level and includes firms with environmental management systems as well as those without such a system.

Environmental innovations can be defined as “... measures of relevant actors (firms, ..., private households), which: (i) develop new ideas, behaviour, products and processes, apply or introduce them, and (ii) contribute to a reduction of environmental burdens or to ecologically specified sustainability targets" (Rennings, 2000, p. 322). Rehfeld et al. (2007) state that the specification of the direction of technological change defined by (ii) is an essential definition criterion for environmental innovations. Rennings (2000) furthermore shows that from (ii) the double externality characteristic of environmental innovations can be derived, which can also be used to delineate them from other innovations. Double externality here means that environmental innovations have, next to the positive externalities from spillovers which are common to all innovations, additionally the characteristic of leading to a reduction of external environmental cost as a negative externality. Next to identifying environmental innovations as a subset of all innovations in an economy, a distinction can also be made in accordance with the Oslo manual (OECD \& Eurostat, 1997) into product innovations (i.e. environmentally-sound product design) and process innovations (process-integrated environmental technologies (see also Ziegler \& Rennings, 2004; Rehfeld et al., 2007). The debate about environmental innovations is embedded in a more general one about sustainability innovations (Smith et al., 2005; Tidd et al., 2005; Weber \& 
Hemmelskamp, 2005) and coordination mechanisms such as markets, regulation or networks (Rennings et al., 2003). In the context of the firm, this is for example relevant for the so-called Porter hypothesis proposing "innovation offsets" from stringent environmental regulation (Albrecht, 1998a, 1998b; Porter \& van der Linde, 1995) which is gradually tightening and economically efficient (Pataki et al., 2003). Strategic niche management (Kemp et al., 1998) and the model of lead markets (BeiseZee \& Rennings, 2005) are other fields of research, partly linked to that of lead users (von Hippel, 1994, 2005; von Hippel et al., 1999) to which studying the determinants of environmental innovations matters. A number of empirical studies have attempted to identify such determinants at the level of the firm as well as for aggregated industries (Brunnermeier \& Cohen, 2003; Hemmelskamp, 1999; Jaffe \& Palmer, 1997; Rennings et al., 2005; Rennings et al., 2006; Ziegler \& Rennings, 2004).

Jaffe and Palmer (1997) analyse the influence of environmental expenditures on innovation activities based on panel data for the U.S. manufacturing sector. They find a positive influence of environmental expenditure on future research and development (R\&D) expenditure, but not on the number of patent applications. However, Brunnermeier and Cohen (2003) criticise that the simultaneous influence of environmental expenditure on R\&D expenditure and patent applications was not modelled and that the number of patent applications did not focus on environmental innovations only. Hemmelskamp (1999) analyses data from the Mannheim Innovation Panel of 1993 based on ordered probit models with regard to the influence of a number of variables on five innovation objectives which he identified by means of factor analysis, amongst which are "development of environmentally-friendly products", "reduction of environmental impacts from production", "reduction of energy input" and "improvement of working conditions“. A focus of the analysis was an assessment of the influence of environmental regulation on innovation activities. This was modelled using an index which evaluated separately for each industry in the sample to which degree it is affected by different regulatory instruments such as taxes or standards. For example, for the development of environmentally-friendly products a significant positive effect of taxes and a somewhat weaker negative influence of standards are found. These results 
point to the relevance of environmental regulations for the realisation of environmental innovations which in more general form is also discussed by Porter and van der Linde (1995). Surprisingly, an influence of environmentally-oriented demand on the development of environmentally-friendly products could not be identified, even though especially environmentally-oriented consumers seem to be well-suited to be lead users for such products (von Hippel, 1994, 2005). A limitation of the research of Hemmelskamp (1999) is that the underlying Mannheim Innovation Panel survey which generated the empirical data was not specifically oriented towards environmental innovations (Rehfeld et al., 2007). Rennings et al. $(2005,2006)$ analyse in their broad-based empirical survey the effects of environmental management systems on firm-level innovation activities and competitiveness based on the European Eco-Audit and Management Scheme (EMAS). Using survey data and detailed case studies, they show that a stronger integration of innovation and environmental management can increase the competitiveness of firms. This finding is based on a telephone survey of 1277 EMAS-validated firms. The analysis finds a positive effect on the realisation of environmental innovations and shows, that the environmental statements required under EMAS strengthen information spillovers in that they are used by other firms to generate ideas for own environmental innovations. The findings also suggest that R\&D departments should be integrated in a stronger way in the EMS development of firms in order to link better corporate strategy and innovation activities. A main conclusion from the study is therefore the need for better linkage of environmental and innovation management. A limitation of the study is that data were only collected for EMAS-verified firms, thereby limiting the generalisability of the identified determinants for environmental innovations to the population of firms in the German manufacturing sector. Ziegler and Rennings (2004) in another study also cast doubt on whether the effects of EMS implementation are related to EMAS validation, since they do not find a significant effect of the latter. Ziegler and Rennings (2004) analyse a sample of German firms ( $\mathrm{n}=588)$ with regard to the effect of EMS and of specific measures such as life cycle analysis or existence of recycling systems on environmental product or process innovations. They are applying binary probit and 
multinomial logit models. In case of the former, only certification according to ISO 14001 has a significant positive effect on firms carrying out either environmental product or process innovations alone. In all other binary models (with product innovation only, process innovation only and simultaneous product and process innovation, respectively) neither ISO certification nor EMAS validation has an effect. Individual measures however do have a significant positive effect. These measures also have a significant positive association with simultaneous product and process innovation in the multinomial logit models analysed. In these, also ISO 14001 certification has a significant positive effect.

\section{MODEL DEVELOPMENT AND FORMULATION OF HYPOTHESES}

This paper tests the hypothesis that environmental management systems (EMS) and particular managerial activities to reduce negative environmental impacts have a positive influence on the probability of firms to pursue environmental innovations. There has been considerable research into the effectiveness and efficiency of EMS in recent years (e.g. Hamschmidt \& Dyllick, 2001; Rennings et al., 2003, 2006; Rennings et al., 2005). The general conclusions from these studies seem to be that ultimate effects of an EMS e.g. on firm profitability or reductions in emissions to air or water or waste production are so large as to imply that emission or waste levels significantly differ from those of firms without an EMS. On the other hand some authors do find evidence of positive association of the degree of EMS implementation on less tangible factors such as innovatory activity of firms (e.g. Hamschmidt \& Dyllick, 2001; Rennings et al., 2005). In addition to this, van Dijken et al. (1999) and Biondi et al. (2002) find that environmental orientation of firms, as reflected in the implementation level of environmental management systems is one important determinant for firms' environmentally related innovation activities in small and medium sized firms, which make up an important proportion of the firms' analysed in this paper. 
Avadikyan et al. (2001) point out that EMS act as a coordination mechanism and show based on case studies that EMS implementation can lead to environmental innovation. They also find, that EMS foster team-based approaches. Together with Llerena (1999) they relate this to learning mechanisms and processes of organisational learning that are strongly oriented towards exploration (March, 1991) and higher order learning (Argyris \& Schön, 1978). This link additionally supports the view that EMS foster environmentally innovation. Also, Llerena (1999) as well as Porter and van der Linde (1995) discuss the possibility of organisational failure in terms of identifying profitable innovation opportunities and show that EMS can help to alleviate this. This implies that EMS implementation should have a positive effect on firms' propensity to carry out environmental innovations, leading to:

Hypothesis 1: A higher level of EMS implementation by a firm results in a higher propensity of that firm to carry out an environmental process or product innovation.

Whether this theoretically derived relationship can be identified empirically can also depend on the way the level of EMS implementation is measured. For example, Rehfeld et al. (2007) and Ziegler and Rennings (2004) measure implementation based on whether firms have or do not have certification or verification according to ISO 14001 or EMAS, the EU Eco-Management and Auditing Scheme. This may be problematic, because asymmetric information may exist in the case of EMS certification that provides incentives for firms to behave opportunistically (Russo, 2001). If it is very difficult for third parties to gather information about the level of environmental performance (including innovatory activity) of a firm with a certified EMS, then the firm may actually have a low level of performance, yet third parties may (erroneously) perceive certification as a signal of high performance. In addition to this, neo-institutional organisational theory (DiMaggio \& Powell, 1983) suggests that certification is a symbolic gesture with little influence on environmental innovations but rather motivated out of institutional isomorphism and mimicry behaviour. Whilst in this view, identification of the relationship predicted in Hypothesis 1 may be difficult, the resource based view (Wernerfelt, 1984) suggests that EMS implementation enables the development of strategic resources and competitive advantages 
resulting from these which have a positive influence on firms' innovatory capabilities and thus on the extent of environmental innovation. If only the resource based view holds true, then EMS certification could be safely interpreted as a signal about competencies of the firm. However even this being the case, the positive influence on innovatory capabilities and extent of environmental innovation is essentially caused by EMS implementation and certification only credibly signals this fact, but is not causally responsible.

From these considerations it becomes obvious that for the purposes of testing Hypothesis 1, it would be desirable to measure the level of EMS implementation independent of certification since one cannot with certainty assume that only the resource based view holds, and that asymmetric information (leading to opportunistic behaviour) and institutional isomorphism (leading to EMS being a purely symbolic gesture without performance effects) can be ruled out fully. Therefore, to measure the EMS influence independent of certification in this research, an index variable was defined based on a number of individual EMS elements. Measuring EMS implementation this way is an improvement on the one hand in that it does not relate to certification and on the other hand in that it is a finer measure than a binary variable.

As noted earlier in the paper, product- or market-related factors emerging from extant literature may well have a positive influence on the propensity of firms to carry out an environmental process or product innovations, independent of the existence of an EMS (regardless of whether certified or not). In addition to that, other organisationally-related factors may also be of relevance and have been identified in the literature (e.g. Strannegard \& Boons, 2000). The factors considered here (based on Brío \& Junquera, 2003; Karl \& Orwat, 1999; Karl \& Orwat, 2000; Lefevre et al., 2003; Noci \& Verganti, 1999; Pujari, 2006) are whether firms inform consumers about environmental effects of products and production processes (market-/product-related outbound marketing), if market research on the potential of "green products" is carried out (market-related inbound marketing), if firms use ecolabelling (Karl \& Orwat, 1999; Karl \& Orwat, 2000) or carry out product recycling (product-related), if 
firms have implemented life cycle assessment (product-/organisationally-related) and if firms carry out benchmarking activities (organisationally-related). For example, Dobers and Wolff (2000) point out that "green" consumers (including stakeholder pressures in a wider sense) represent a market pull that motivates firms towards environmental innovation and also Foster and Green (2002) conclude that environmental innovation depends much on environmentally-driven users. This is not to say, that they are the exclusive factor for such innovations, but that evaluating the preferences of such consumers through market research and providing feedback to the customers about the environmental quality of the resulting products and processes by means of information dissemination and by means of signalling through eco-labelling seem to be important variables that are (as "soft" issues) more relevant today compared to regulation, technological trajectories or similar "hard" issues (Dobers \& Wolff, 2000). Recycling systems for a firm's products and life-cycle analysis have been identified as an important factor related to environmental innovation (e.g. Sharma \& Henriques,2005; Noci \& Verganti, 1999; Pujari, 2006; Lefevre et al., 2003). For all of the above variables, respondents had to state whether their firm carried out the measure or not and based on the literature, a positive influence is expected on the propensity to innovate, leading to:

Hypothesis 2: There is an effect from a firm's adoption of managerial activities not required to form part of a certified EMS in that informing customers, life cycle assessment, market research on green products, recycling, benchmarking and eco-labelling have an additional positive effect on a firm's propensity to carry out an environmental process or product innovation.

A difference of this research to earlier studies is that it uses environmental process and product innovations already carried out by the firm (in the three years preceding the survey) as the dependent variable (any non-structural variables used as explanatory variables also refer to this period of time). Ziegler and Rennings (2004) point out that this could lead to problems of endogeneity which could be reduced or avoided by using information about environmental innovations planned in future or by using 
lagged dependent variables. On the other hand, using future-oriented statements implies greater uncertainty with regard to firms actually innovating in the way they state and imply potentially higher response bias due to social desirability. These problems are avoided when using the innovations already carried out as the dependent variable. In addition to this argument for my dependent variable, Rehfeld et al. (2007) find a very high correlation of environmental innovations carried out and planned in the case of both product and process innovations. Therefore results should be very similar regardless of whether planned or actual innovations are used in the analysis.

Next to endogeneity issues, Ziegler and Rennings (2004) also perceive problems resulting from the influence environmental innovations have on specific environmental management activities. For example it may be rational for a firm to introduce a recycling system (as a specific activity) only after it has carried out an environmental product innovation because the recycling system is essentially part of the product innovation. However, this is not necessarily the case, if for example the recycling system is a generic one which can be applied to a number of products (old and new) that the firm produces. In this case, the existence of such a recycling system provides incentives for carrying out further environmental product innovations (as long as it has not reached its capacity limit) because these innovations enable the distribution of the system's operating cost across a larger product quantity. A similar line of argument also applies to eco-labelling as a predictor for environmental innovations and this makes a endogeneity bias unlikely.

\section{RESEARCH METHOD AND ANALYSIS}

Data Set.

The empirical analysis for which results are presented in the following section is based on data collected during the European Business Environment Barometer (EBEB) survey. This was a bi-annual survey on the state of environmental management in practice carried out in several European countries based on a mail questionnaire. The questionnaire asked firms for a self-assessment of their main 
environmental effects and stakeholder demands; for their innovation and environmental management activities and for general information about the firm and its structure. ${ }^{1}$ The data is based on the last EBEB survey round in 2001 carried out in nine European countries (Belgium, France, Germany, Hungary, Netherlands, Norway, Sweden, Switzerland, United Kingdom). Prior work provides some descriptive results and some comparison of the effects that several stakeholders have on the companies, the relevance of different management and technology measures as well as influences of strategy choice (Baumast \& Dyllick, 2001).

In the 2001 EBEB round, almost 2100 firms in the manufacturing industries were surveyed Europewide based on random sampling, corresponding to an average response rate of $26 \%$. As concerns response bias, it is possible that the replies received contain over-proportionally many firms that are particularly active in terms of environmental management. Such a bias is a frequent problem of surveys based on written questionnaires (Armstrong \& Overton, 1977). However, in the case of the German responses, the characteristics and response behaviour of early respondents was not significantly different from the late replies, based on comparison of means for all variables used between the first and last $10 \%$ of respondents, except for a slightly higher level of environmental activities of the latter. Also, there is no unique definition of environmentally active/innovative firms and earlier studies partly had relatively high numbers in their sample. Rehfeld et al. (2007) categorised only 20\% of their respondents as not carrying out environmental product or process innovations, whilst Hemmelskamp (1999) classified only 33\% and Ziegler and Rennings (2004) only $27 \%$ of their respondents as not being environmentally innovative. With $35 \%$ of respondents classified this way my research has more firms that do not carry out any environmental innovations. As well, only $26 \%$ of the firms in my research carry out both, environmental product and process innovations, compared to $30 \%$ in Rehfeld

\footnotetext{
${ }^{1}$ The full questionnaire can be accessed in English at www.agf.org.uk/pubs/pdfs/UK.pdf
} 
et al. (2007), 31\% in Ziegler and Rennings (2004) and 50\% in Hemmelskamp (1999). If anything, this indicates that the data analysed here lead to results that are more conservative than in earlier studies.

\section{Regression Model.}

The EBEB survey asked in two questions about environmental product and process innovations in general ("green" design of a new product in the years 1998-2000 and implementation of cleaner technology during the same period). These were used as the dependent variables in the research. Firms could answer these questions with "yes" or "no" or could choose that a question was not applicable to their circumstances in which case they were excluded from the analysis. Based on these dependent variables, the study applies binary and multinomial discrete choice models (Greene, 2002; Hair et al., 1998). More specifically, in a first analysis step a multivariate probit model (Greene, 2002: 714-719) was used which is appropriate when error terms are correlated, after the influence of the explanatory variables in the model is accounted for (Greene, 2003: 717). This is the case when two binary dependent variables can both occur simultaneously or only one of them can occur and the other not.

In a second analysis step, a multinomial logit model was estimated under the same conditions as the multivariate probit model in order to identify the main determinants for the progression in the level of innovatory activity (in terms of whether firms do not carry out any innovation at all, carry out exclusively product or process innovations, or pursue both types of innovation simultaneously) beyond the innovation type (product or process innovation). The independent variables for all models were based on prior empirical work in industrial economics (Nguyen Van et al., 2004; Schmalensee, 1989; Wagner, 1992; 1995), innovation economics (Tidd et al., 2005; Ziegler \& Rennings, 2004) and environmental management research (e.g. Brío \& Junquera, 2003; Lefevre et al., 2003; Russo, 2001; Wagner \& Schaltegger, 2004). Next to industry membership and the environmental management variables already introduced in Section 2, they include a significant number of explanatory factors such 
as country origin of a firm, firm size, existence of a quality management system (dummy variable taking value 1 if firm has ISO 9001) and firm legal structure.

Sector membership is measured by dummy variables based on two-digit NACE codes with firms in the metal products sector being the reference group. EMS implementation is defined as the sum of activities based on 10 elements (variable mean: 5.7; standard deviation: 3.5 ). ${ }^{2}$ The sum variable was strongly associated with another question asking for the EMS implementation levels on a 4-point scale, which additionally validates the measure. The variables for managerial activities not required to form part of an EMS refer to agreement or not with whether the firm carries out market research on green products; informs consumers about environmental effects of products and processes; makes use of ecolabelling; as implemented product life cycle analysis, carries out benchmarking and carries out product recycling.

Country membership was measured using dummy variables for each country with firm location in the Netherlands being the reference group omitted in the regression. As concerns other control variables, firm size was measured by the logarithm of the number of employees (in thousands), firm age as the logarithm of firm age in 2001 (in years) and firm legal status (in terms of a dummy variable taking unity value if the firm is solely owned). In addition to these variables, following Ziegler and Rennings (2004) I include a dummy measure taking the value of 1 if environmental aspects have competitive relevance for a firm.

Using these explanatory variables, I initially estimate a multivariate probit model with a more limited specification in order to test Hypothesis 1 of Section 2 above alone, i.e. whether there is a significantly

\footnotetext{
2 The ten EMS elements were: written environmental policy, procedure for identification and evaluation of legal requirements, initial environmental review, definition of measurable environmental goals, programme to attain measurable environmental goals, clearly defined responsibilities, environmental training programme, environmental goals are part of a continuous improvement process, separate environmental/health/safety report or environmental statement and audit system to check environmental programme. The scale ranged from zero (no activity carried out) to 10 (all listed activities carried out).
} 
positive EMS influence on the probability of environmental innovation activities (Table 1). I then use a more extended specification by adding the variables used to operationalise Hypothesis 2 of Section 2 additionally to the model (Table 2). This stepwise approach reveals if they have additional explanatory value for the propensity to carry out environmental innovations beyond the variables already included in the limited specification, as proposed by Hypothesis 2 in Section 2. Data for all countries surveyed are pooled, whilst introducing a dummy variable for each country to control for differences across countries. Because the benchmarking, product recycling and life-cycle assessment variables were not significant in the all model specifications, they were excluded from the final models presented here for reasons of parsimony.

For the second analysis step, instead of a multivariate, a three-category multinomial logit model is used which distinguishes between firms carrying out neither an environmentally-related process nor a product innovation, firms that carry out exactly one of these two and firms carrying out both types of environmental innovations. Again, the corresponding multinomial models are first estimated (in Table 3) based on the limited model specification including only the EMS implementation variable and subsequently (in Table 4) using the extended specification including again the three managerial activity variables relating to activities not forming part of an EMS which were found to be significant in the regression models.

\section{RESULTS}

Table 1 provides the results of the estimation without including managerial activity variables outside an EMS as well as several important statistics providing information about the quality of the estimation. As can be seen, based on the corresponding Likelihood Ratio (LR) test, the assumption that the error terms are uncorrelated can be rejected, confirming the use of a multivariate probit model being more appropriate than estimating two independent binary probit models. In addition, the model is overall significant. 
Insert Table 1 about here

Table 2 provides results after inclusion of the three additional variables for the managerial activities going beyond those linked to EMS implementation. Again, this extended multivariate probit model is overall significant and the hypothesis of (weakly) correlated error terms cannot be rejected.

Insert Table 2 about here

Industry effects in the multivariate probit model.

I find that a number of industry dummies which have been included to address industry-specific effects are significant for both environmental product as well as process innovations in the limited multivariate probit model including only the EMS variable. Industry effects become somewhat weaker in the extended multivariate probit model, but where they remain significant it is for the same sectors as before.

Environmental management effects and hypothesis testing in the multivariate probit model.

The most important finding is that Hypothesis 1 can be confirmed in the limited multivariate probit model in that EMS implementation has a significant positive effect on both product and process innovations. Opposed to this, the EMS variable is in the extended multivariate probit model only significantly positive for process innovations.

To test Hypothesis 2 which proposes that there is an effect beyond EMS implementation from a firm's adoption of managerial activities not required in an EMS the extended multivariate probit model. These activities were the information of customers, market research on green products and eco-labelling. All 
three have an additional positive effect on a firm's propensity to carry out an environmental product innovation, which is strongest for market research, and the latter has also a positive effect on process innovations. The effect is strongest for market research.

Country effects in the multivariate probit model.

The strongest significant country effect in the limited multivariate probit model is the one for Germany, which is positive for process and product innovations. For Hungary and Switzerland significant negative effects are found. The strongest significant country effect in the extended multivariate probit model is again found for Germany but is now only positive for product innovation. As before, significantly negative effects for Hungary and Switzerland, but also for the United Kingdom are found. The second approach to analyse the hypotheses in the empirical analysis identifies the determinants under which environmental product and process innovations are carried out separately or simultaneously, using the same explanatory variables as before. The results are summarised in Tables 3 and 4 .

Insert Table 3 about here

Insert Table 4 about here

Industry effects in the multinomial logit model.

As for the multivariate probit model, also in the multinomial logit model significant industry effects exist. For firms in the paper and chemicals industries these are positive in the limited model for firms carrying out process and product innovations simultaneously, whereas for the energy industry it is negative. Only the paper industry dummy has also a positive effect for firms carrying out exactly one type of innovation (either product process), and here also the leather industry has a significant effect 
which is however negative. This changes in the extended multinomial logit model in that only negative effect for the leather industry remains significant, indicating that the additionally introduced variables pick up some of the variance that previously was in the industry dummies.

Environmental management effects and hypothesis testing in the multivariate probit model.

As can be seen in Table 3 for the (limited) model without activity variables a significant positive association with the probability to simultaneously carry out "green" product development and to implement cleaner technology (relative to carrying out no environmental innovation) is found for EMS implementation as is a positive association of EMS implementation with whether firms carry out either product or process innovation, relative to firms not carrying out any environmental innovation at all. In the extended multinomial logit model, the association of EMS implementation level weaken considerably for both simultaneously and separately carrying out process and product innovation.

Country effects in the multinomial logit model.

For the limited multinomial logit model, Germany has a significant positive influence (relative to the Netherlands) on both firms carrying out simultaneous product and process innovations and on firms carrying out only one of them relative to carrying out no environmental innovations at all. For the model based on the extended specification (including the managerial activity variables) it is found that the effect for Germany on simultaneous product and process adoption relative to no adoption weakens (compared to the limited specification) from 1.11 to 0.85 , whereas that for carrying out one of the two types of innovation (relative to none) stays almost the same.

\section{DISCUSSION}

Two hypotheses were tested in this research in two analysis steps, based on multivariate and multinomial probit/logit models. Hypothesis 1 was that EMS implementation (independent of EMS certification) has a positive effect on firms carrying out environmentally-related product or process 
innovations. This could be confirmed in the multivariate probit model, indicating that EMS implementation likely triggers more systematic search processes for environmental innovation and seems to lead to learning processes triggered by the implementation of an EMS. However, this needs to be qualified for the multivariate probit model as Hypothesis 2 was confirmed whilst the EMS implementation effect became insignificant.

The difference of the effects of EMS between the multivariate probit and multinomial logit model is explained by the different combination of product or process innovations in both models. The stylized fact common to both models is however, that when additional variables measuring activities not required in an EMS are involved, the significance of EMS becomes less or even disappears completely, indicating that the additional variables are better predictors taking away variance explained from the EMS variable. In the case of the multinomial logit model the estimation refers (other than in the multivariate probit model) in both cases to a joint process-product innovation variable. Therefore the remaining association found for EMS is stronger (and thus remains significant, but at lower levels and with a lower strength of the association compared to the multivariate logit model in which the association on product innovation is isolated), but this does not contradict the stylized fact described above and the insight that EMS seem to mainly associate with process innovation.

This change of the EMS implementation level in the extended multivariate/multinomial probit/logit models means that product innovation is associated with the managerial activity variables, rather than EMS implementation. In case of the additional activities, the strongest effect was found for market research, followed by eco-labelling and informing consumers and market research also had an effect on process innovation. In the following I discuss causal mechanisms that can explain why the managerial activity variables, rather than EMS implementation, are associated with product innovation. Market research on "green" products likely leads to a better understanding of profitable demand for product innovations with environmental benefits, for example in cooperation with lead users. As well, it enables firms to identify environmentally oriented customer segments. Therefore, its strong positive 
effect on environmental product innovations can be well explained. The additional effect on process innovations is more surprising, it may however be explained by the fact that an environmental product innovation can also imply changes in the production process required. Rubik and Teichert (1997, p. 24) suggest that for reasons of reputation and credibility firms forcing environmental product innovation also need to show above-average environmental performance in production which may imply simultaneous promotion of environmental process innovations.

Experience with eco-labelling may result into better knowledge about the benefits of this activity. If a firm has already positive experiences with eco-labelling then its incentive to develop environmentallysound products which are suitable for labelling should increase and this can explain the observed positive effect of eco-labelling on environmental product innovations. This is because from the perspective of customers, the choice is essentially one between products with or without an eco-label. For example, whilst in the case of electricity (discussed e.g. by Truffer et al., 2001), the environmental quality is actually brought about by the production process (production of electricity through photovoltaic processes or using biomass), the customers choose between electricity tariffs as products. Also, e.g. in the case of appliances, the product is exclusively the focus of eco-labelling (Banerjee \& Solomon, 2003). Reverse causality cannot be ruled out completely in the case of eco-labelling with the data at hand (since this would require panel data). Yet, since in half of all theoretically possible sequences of innovation and labelling (which each can take place in 1998, 1999 or 2000), the product innovation takes place before eco-labelling at least some positive effect from prior eco-labelling experiences on environmental product development can be expected and can thus explain the significant positive effect observed empirically.

Finally, it has been argued that for labels to be effective, organisations need to enter into a dialogue with customers or other stakeholders to learn about societal expectations that need translation into business practices certified through labelling (Boer, 2003). This implies that eco-labelling is in many 
ways essentially a learning process and strengthens the argument that it leads to innovation when what was learned gets implemented.

The third managerial activity variable introduced is that of informing consumers on environmental effects of products and production processes. Doing so may induce additional demand if an environmentally oriented customer segment exists and therefore increase the incentive and thus the probability of a firm carrying out an environmental product innovation. Again reverse causality can not be ruled out in that information provision can happen before or after the product innovation is carried out. However, in the latter case, no effect on the propensity to carry out a product innovation should exist, and therefore the joint effect should be positive but may be understated if in many cases information took place after the product innovation, i.e. the reported coefficient is conservative in this sense. Nevertheless, the empirical result can be explained by this logic. Also, the insignificant effect on process innovations of informing consumers is plausible, since their decisions focus on products and even in the case of information about production processes, these will manifest in buying a particular product for which some related improvement of the production process took place.

An important finding of this research is also that the use of EMS certification as a measure for EMS implementation (rather than an activity-based measure as used here) is a possible explanation for its insignificant effect on environmental innovations in other empirical studies (e.g. Ziegler \& Rennings, 2004). EMS basically work through their implementation level but not by means of certification which either takes place after implementation or even not at all. In order to directly test the role of citations, the regression models were also run with additional dummy variables for EMAS and ISO 14001 certification included. The certification dummies where insignificant for both, product and process innovations, regardless of whether EMAS or ISO certification is considered. Also no significant associations were identified for an of interaction term of the certification dummy and the original EMS 
implementation variable which was additionally introduced in the model. This confirms the initial argument that implementation is potentially a less confounded measure than EMS certification. ${ }^{3}$

The motivation for the second analysis step is that the relevance of factors may differ depending on whether firms carry out either environmental product or process innovation neither of them, or both. Therefore, in the second analysis step, I applied a multinomial logit model to the data, results of which are reported in the Section 4. In line with the results of the first analysis step, I find that both, EMS implementation level and the different managerial activities outside of it have also positive effects on simultaneous realisation of environmental product and process innovation.

As concerns the limitations of the study variation in response rate by countries self-selection of respondents and self-assessment need to be acknowledged. However, as concerns response rate variations as an indication of possible self-selection, other than low responses of small firms (implying that the replies received contain over-proportionally many firms of larger size), no systematic nonresponse of specific groups of firms was found. Self-assessment is mainly a concern in terms of common method bias, but testing for this using Harman's single factor test indicated that this is not an issue. Also, a number of procedural steps where undertaken during the preparation and implementation of the survey to minimise the risk of common method bias occurring.

In addition to these limitations the European focus of the analysis needs to be acknowledged as one feature of the research that may limit transferability of the findings in light of the institutional differences to other regions. A European focus on the other hand is complementary in that most extant research on the performance link has been carried out on US data. The country differences identified with regard to environmental innovation indicate, that in Germany above-average levels of environmental innovation are found, whereas in Switzerland, Hungary and the UK environmental

\footnotetext{
${ }^{3}$ I am grateful to one reviewer to pointing out the possibility of more direct testing of this argument regarding certification. The results of the respective estimations are not reported here for brevity, but are available from the author on request.
} 
innovation levels are below average, especially with regard to environmental product innovation. The significantly higher levels in Germany, relative to other European countries are likely related to the more stringent environmental regulation there. Also, liberalization in some important areas of the economy could explain the above-average performance in Germany (see e.g. Markard and Truffer (2006) for an account of how innovation practices can change due to sector deregulation). The lower levels of environmental innovation in Switzerland for both product and process innovation could be related to the predominance of the service sector (especially banking and insurance) in the Swiss economy. Given this predominance, many manufacturing firms in Switzerland are subsidiaries of international firms which makes embodied environmental technology transfer (rather than innovation activity in the subsidiary) more likely (Lanjouw \& Mody, 1996; Rabbiosi et al., 2007). Similar arguments apply to Hungary, where after 1990 the industrial sector was largely rebuilt through foreign direct investment of multinational corporations and related embodied environmental technology transfer (e.g. Rondinelli \& Vastag, 1999). For the UK, it seems that the less stringent regulatory environment is an important explanatory factor.

Finally, the binary dependent variable used in this analysis could certainly be improved upon. For example, it could help to have at least an ordinal evaluation or even data on environmentally related patenting activities of firms. ${ }^{4}$ However, collecting ordinal data on environmental innovations was considered to have a negative influence on the response rate to the survey, given its already considerable length. Also, no agreed definition constitutes of what environmentally related patenting consists of and agreeing on such a definition was unfortunately beyond the scope. Nevertheless future

\footnotetext{
${ }^{4}$ To validate the binary dummy variable for environmental innovation used in this study it was triangulated for the German firms with patent data. This showed, that for both, environmental product and process innovation there is a significant association with whether or not firms are patenting (i.e. firms that patent are more likely to also carry out environmental product/process innovation and one that does not patent is less likely to do so). Also, the average number of patents is significantly higher for firms stating they carry out environmental product or process innovations. To take the validation one step further, for the German firms, for which patent data could be collected, environmental patents were singled out by means of keyword searches in the patent titles and abstracts. Here again, a significant association was found with the direction described before. Also, the mean number of environmental patents is significantly higher for firms that stated to carry out environmental product/process innovations. The underlying tests are available on request.
} 
research could improve upon and hopefully confirm the findings reported here with more detailed measures of environmental innovation activities. ${ }^{5}$

\section{REFERENCES}

Argyris, C. and Schön, D., 1978. Organisational Learning: A Theory of Action Perspective. AddisonWesley, Reading.

Albrecht, J., 1998a. Environmental Regulation, Comparative Advantage and the Porter Hypothesis.

Working Paper, Faculty of Economics and Applied Economics, University of Ghent.

Albrecht, J., 1998b. Environmental Costs and Competitiveness. A Product-Specific Test of the Porter

Hypothesis. Working Paper, Faculty of Economics and Applied Economics, University of Ghent.

Armstrong, J.S. and Overton, T.S., 1977. Estimating Non-Response Bias in Surveys. Journal of Marketing Research, XIV(August): 396-402.

Avadikyan, A., Llerena, D. and Ostertag, K., 2001. Organisational Mechanisms in Environmental Management: an Evolutionary Analysis confronted with Empirical Facts. International Journal of Environmental Technology and Management, 1(1-2): 45-60.

Banerjee, A. \& Solomon, B.D., 2003. Eco-labeling for energy efficiency and sustainability: a metaevaluation of US programs. Energy Policy, 31: 109-123.

Baumast, A. and Dyllick, T., 2001. Umweltmanagement-Barometer 2001. Institute for Economy and the Environment, University of St. Gallen, St. Gallen.

Beise-Zee, M. and Rennings, K., 2005. Lead Markets and Regulation: A Framework for Analyzing the International Diffusion of Environmental Innovation. Ecological Economics, 52(1): 5-17.

\footnotetext{
${ }^{5}$ The research underlying this paper was supported by a Marie Curie Intra-European Fellowship within the 6th European Community Framework Programme. Comments from two anonymous referees are gratefully acknowledged, as is feedback at the DIMETIC 2006 Summer School, IFSAM 2006 Conference, DRUID Summer Conference 2007, and Academy of Management 2007 Conference. Suggestions that helped to improve the paper were also received from Joachim Henkel, Ans Kolk and Dora Nikolaidou.
} 
Biondi, V., Iraldo, F. and Meredith, S., 2002. Achieving sustainability through environmental innovation: the role of SMEs. International Journal of Technology Management, 24(5-6): 612-626. Boer, J. de, 2003. Sustainability labelling schemes: the logic of their claims and their functions for stakeholders. Business Strategy and the Environment, 12(4): 254 - 264.

Brio, J.A. and Junquera, B., 2003. A review of the literature on environmental innovation in SMEs: implications for public policies. Technovation, 23: 939-948.

Brunnermeier, S.B. and Cohen, M.A., 2003. Determinants of environmental innovations in US manufacturing industries. Journal of Environmental Economics \& Management, 45: 278-293. DiMaggio, P. and Powell, W., 1983. The Iron Cage Revisited: Institutional Isomorphism and Collective Rationality in Organizational Fields. American Sociological Review, 48(April): 147-160. Foster, C. and Green, K., 2002. Environmental innovation in industry: the importance of environmenttally-driven users. International Journal of Environmental Technology and Management, 2(4): 303314.

Hair, J.F., Anderson, R.E., Tatham, R.L. and Black, W.C., 1998. Multivariate Data Analysis with Readings (5th edition). Prentice Hall, Englewood Cliffs.

Hamschmidt, J. and Dyllick, T., 2001. ISO 14001: Profitable? Yes! But is it eco-effective?. Greener Management International, 34(Summer): 43-54.

Hemmelskamp, J., 1999. Umweltpolitik und technischer Fortschritt. Eine theoretische und empirische Untersuchung der Determinanten von Umweltinnovationen. Physica, Heidelberg.

Jaffe, A. and Palmer, K., 1997. Environmental Regulation and Innovation: A Panel Data Study. Review of Economics and Statistics, 79(4): 610-619.

Karl, H. and Orwat, C., 1999. Economic aspects of environmental labeling. In: Folmer, H. and Tietenberg, T. (Editors), The International Yearbook of Environmental and Resource Economics 1999/2000. Edward Elgar, Cheltenham, pp. 107-170 
Karl, H. and Orwat, C., 2000.Environmental marketing and public policy. In: Folmer, H. and Gabel, H.L. (Editors), Principles of Environmental and Resource Economics. Edward Elgar, Cheltenham, pp. 363-395.

Kemp, R., Schot, J. and Hoogma, R., 1998. Regime Shifts to Sustainability through Processes of Niche Formation. The Approach of Strategic Niche Management. Technology Analysis and Strategic Management, 10(2): 175-195.

Lanjouw, J. O. and Mody, A., 1996. Innovation and the international diffusion of environmentally responsive technology. Research Policy, 25: 549-571.

Lefevre, E. and Lefevre, L.A. and Talbot, S., 2003. Determinants and impacts of environmental performance in SMEs. $R \& D$ Management, 33(3): 263-283.

Llerena, D., 1999. Integration of environmental issues in the firm: learning processes and coordination. International Journal of Sustainable Development, 2(2): 263-282.

March, J., 1991. Exploration and Exploitation in Organisational Learning. Organisation Science, 2: 7187.

Markard, J. and Truffer, B., 2006. Innovation processes in large technical systems. Market liberalization as a driver for radical change? Research Policy, 35: 609-625.

Nguyen Van, P., Kaiser, U. and Laisney, F., 2004. The Performance of German Firms in the BusinessRelated Service Sectors. Journal of Business and Economic Statistics, 22(3): 274-295.

Noci, G. and Verganti, R., 1999. Managing "green" product innovation in small firms. $R \& D$ Management, 29(1): 3-15.

OECD and Eurostat. 1997. Proposed Guidelines for Collecting and Interpreting Technological Innovation Data - Oslo-Manual. OECD/Eurostat, Paris.

Porter, M. and van der Linde, C., 1995. Toward a New Conception of the EnvironmentCompetitiveness Relationship. Journal of Economic Perspectives, 9(4): 97-118. 
Pataki, G., Bela, G. and Kohlheb, N., 2003. Competitiveness and Environment Protection. Working Paper, Hungarian Ministry of Finance, Budapest. (accessed at http://www.pm.gov.hu on 12 June 2007). Pujari, D., 2006. Eco-innovation and new product development: understanding the influences on market performance. Technovation, 26: 76-85.

Rabbiosi, L., Mudambi, R. and Piscitello, L., 2007. Mandates and Mechanisms: the Impact on Reverse Knowledge Transfer in MNEs, Paper presented at the 2007 DRUID Summer Conference, Copenhagen (accessed at http://www.druid.dk/summer2007 on 21 June 2007).

Rehfeld, K.M., Rennings, K. and Ziegler, A., 2007. Integrated Product Policy and Environmental Product Innovations: An Empirical Analysis. Ecological Economics, 61(1): 91-100.

Rennings, K., 2000. Redefining Innovation - Eco-Innovation Research and the Contribution from Ecological Economics. Ecological Economics, 32(2): 319-332.

Rennings, K., Kemp, R., Bartolomeo, M., Hemmelskamp, J. and Hitchens, D. (Editors), 2003. Blueprints for an Integration of Science, Technology and Environmental Policy. ZEW, Mannheim. Rennings, K., Ziegler, A., Ankele, K. and Hoffmann, E., 2006. The Influence of Different Characteristics of the EU Environmental Management and Auditing Scheme on Technical Environmental Innovations and Economic Performance: Ecological Economics, 57(1): 45-59. Rennings, K., Ankele, K., Hoffmann, E., Nill, J. and Ziegler, A., 2005. Innovationen durch Umweltmanagement: Empirische Ergebnisse zum EG-Öko-Audit. Springer, Berlin.

Rondinelli, D. and Vastag, G., 1999. Multinational Corporations’ Environmental Performance in Developing Countries: The Aluminium Company of America. In: Wehrmeyer, W. and Mulugetta, Y. (Editors), Growing Pains - Environmental Management in Developing Countries. Greenleaf, Sheffield, pp. 84-100.

Rubik, F. and Teichert, V., 1997. Ökologische Produktpolitik. Von der Beseitigung von Stoffen und Materialien zur Rückgewinnung in Kreisläufen. Schäffer-Poeschel, Stuttgart. 
Russo, M.V., 2001. Institutional Change and Theories of Organizational Strategy: ISO 14001 and Toxic Emissions in the Electronics Industry. Working Paper, University of Oregon, Eugene, (accessed at http://lcb1.uoregon.edu/mrusso/ISOStudy.htm on 13 February 2007).

Scherer, F.M., 1992. Schumpeter and Plausible Capitalism. Journal of Economic Literature, XXX: 1416-1433.

Schmalensee, R., 1989. Inter-Industry Studies of Structure and Performance. In: Schmalensee, R. and Willig, R.D. (Editors), Handbook of Industrial Organization. North Holland, Amsterdam, pp. 9511009.

Schumpeter, J., 1934. The Theory of Economic Development. Harvard University Press, Cambridge. Schumpeter, J., 1943. Capitalism, Socialism and Democracy. Harper, New York.

Sharma, S. and Henriques, I., 2005. Stakeholder Influences on Sustainability Practices in the Canadian Forest Products Industry. Strategic Management Journal, 26: 159-180.

Smith, A., Stirling, A. and Berkhout, F., 2005. The governance of sustainable socio-technical transitions. Research Policy, 34: 1491-1510.

Strannegard, L. and Boons, F. 2000. Organizations coping with their natural environment: a laboratory for institutionalization? International Studies of Management and Organization, 30(3): 7-17.

Tidd, J., Bessant, J. and Pavitt, K., 2005. Managing Innovation (3rd edition). Wiley, Chichester. Truffer, B., Markard, J. and Wüstenhagen, R., 2001 Eco-labeling of electricity: strategies and tradeoffs in the definition of environmental standards, Energy Policy, 29(11): 885-897.

Utterback, J.M. and Abernathy, W.J., 1975. A Dynamic Model of Process and Product Innovation. OMEGA, 6: 639-656.

van Dijken, K., Prince, Y., Wolters, T., Frey, M., Mussari, G., Kalff, P., Hansen, O., Kerndrup, S., Sondergard, B., Rodrigues, E.L. and Meredith, S., 1999. The Dynamics of Innovation as Interplay between Business Competence, Environmental Orientation and Network Involvement. Kluwer: Dordrecht. 
von Hippel, E., 1994. Sticky Information and the Locus of Problem Solving: Implications for Innovation. Management Science, 40(4): 429-439.

von Hippel, E., Thomke, S. and Sonnack, M., 1999. Creating Breakthroughs at 3M. Harvard Business Review, September-October: 47-57.

von Hippel, E., 2005. Democratizing Innovation. MIT Press, Cambridge.

Wagner, J., 1992. Firm Size, Firm Growth, and Persistence of Chance: Testing Gibrat's Law with Establishment Data from Lower Saxony, 1978-1989. Small Business Economics, 4: 125-131.

Wagner, J., 1995. Firm Size and Job Creation in Germany. Small Business Economics, 7: 469-474. Wagner, M. and Schaltegger, S., 2004. The Effect of Corporate Environmental Strategy Choice and Environmental Performance on Competitiveness. European Management Journal, 22(5): 557-572. Weber, M. and Hemmelskamp, J. (Editors), 2005. Towards Environmental Innovation Systems. Springer, Heidelberg.

Wernerfelt, B., 1984. A resource-based view of the firm. Strategic Management Journal, 5: 171-180. Ziegler, A. and Rennings, K., 2004. Determinants of Environmental Innovations in Germany: Do Organizational Measures Matter? Discussion Paper No. 04-30, ZEW, Mannheim. 


\section{TABLE 1}

Multivariate probit model of product and process innovation ${ }^{\mathrm{a}}$

\begin{tabular}{|c|c|c|}
\hline Type of environmental innovation & Product innovation & Process innovation \\
\hline Food and tobacco & $0.14(0.18)$ & $-0.02(0.17)$ \\
\hline Textile products & $0.62(0.25)^{*}$ & $0.19(0.28)$ \\
\hline Leather products & $0.44(0.87)$ & $-0.07(0.78)$ \\
\hline Wood products & $0.48(0.26)^{\dagger}$ & $-0.41(0.25)$ \\
\hline Pulp and paper products & $0.84(0.25)^{* *}$ & $0.33(0.26)$ \\
\hline Publishing and printing & $0.45(0.23)^{\dagger}$ & $0.003(0.23)$ \\
\hline Energy, cokes and oil fuel & $0.11(0.62)$ & $-4.91(0.24) * * *$ \\
\hline Chemical products and fibres & $0.69(0.19)^{* *}$ & $0.15(0.19)$ \\
\hline Rubber and plastics & $0.30(0.20)$ & $-0.51(0.19)^{* *}$ \\
\hline Non-ferrous mineral products & $0.86(0.31)^{* *}$ & $-0.29(0.27)$ \\
\hline Machines and equipment & $0.63(0.19)^{* *}$ & $-0.08(0.18)$ \\
\hline Electrical and optical equipment & $0.70(0.21)^{* *}$ & $-0.07(0.20)$ \\
\hline Transport products & $0.70(0.28)^{*}$ & $-0.29(0.26)$ \\
\hline Other manufacturing & $0.52(0.17)^{* *}$ & $-0.13(0.16)$ \\
\hline Germany & $0.52(0.17) * *$ & $0.27(0.16)^{\dagger}$ \\
\hline Sweden & $-0.20(0.15)$ & $0.10(0.14)$ \\
\hline Switzerland & $-0.08(0.23)$ & $-0.44(0.22)^{*}$ \\
\hline United Kingdom & $-0.20(0.19)$ & $0.12(0.18)$ \\
\hline Hungary & $-1.28(0.44)^{* *}$ & $0.46(0.39)$ \\
\hline France & $0.02(0.22)$ & $-0.01(0.21)$ \\
\hline
\end{tabular}


Belgium

Norway

Firm age

Quality management system

Firm size

Company in sole proprietorship

Environmental management system

index

Environment as competitive factor

Constant

Likelihood ratio test of correlation
No. of observations

Log likelihood

$\mathrm{R}$ process innovation, product innovation
$-0.12(0.17)$

$-0.06(0.20)$

$0.26(0.13)^{*}$

$0.09(0.13)$

$0.04(0.02)$

$0.14(0.11)$

$0.05(0.02)^{* *}$
$0.12(0.16)$

$-0.25(0.19)$

$-0.12(0.13)$

$0.04(0.12)$

$0.03(0.02)^{\dagger}$

$0.08(0.10)$

$0.10(0.02)^{* * *}$
$0.70(0.11)^{* * *}$
$0.20(0.11)^{*}$

$-1.87(0.30) * * *$

$-0.44(0.28)$

849

$-1004.47$

$0.26 * * *$

a Robust standard errors in parentheses; ${ }^{\dagger} \mathrm{p}<.10 ; * \mathrm{p}<.05 ; * * \mathrm{p}<.01 ; * * * \mathrm{p}<.001$ 


\section{TABLE 2}

Multivariate probit model of product and process innovation with managerial activity variables ${ }^{\mathrm{a}}$

\begin{tabular}{|c|c|c|}
\hline Type of environmental innovation & Product innovation & Process innovation \\
\hline Food and tobacco & $0.08(0.20)$ & $-0.04(0.18)$ \\
\hline Textile products & $0.41(0.27)$ & $0.13(0.28)$ \\
\hline Leather products & $0.39(0.74)$ & $-0.007(0.74)$ \\
\hline Wood products & $0.04(0.29)$ & $-0.53(0.26)^{*}$ \\
\hline Pulp and paper products & $0.33(0.30)$ & $0.13(0.27)$ \\
\hline Publishing and printing & $0.23(0.27)$ & $-0.17(0.26)$ \\
\hline Energy, cokes and oil fuel & $0.06(0.49)$ & $-5.04(0.22) * * *$ \\
\hline Chemical products and fibres & $0.59(0.23) * *$ & $-0.01(0.20)$ \\
\hline Rubber and plastics & $0.29(0.22)$ & $-0.50(0.20)^{*}$ \\
\hline Non-ferrous mineral products & $0.84(0.32)^{* *}$ & $-0.27(0.29)$ \\
\hline Machines and equipment & $0.63(0.21)^{* *}$ & $-0.07(0.19)$ \\
\hline Electrical and optical equipment & $0.54(0.25)^{*}$ & $-0.15(0.23)$ \\
\hline Transport products & $0.77(0.33)^{*}$ & $-0.33(0.28)$ \\
\hline Other manufacturing & $0.59(0.19)^{* *}$ & $-0.13(0.18)$ \\
\hline Germany & $0.39(0.19)^{*}$ & $0.20(0.18)$ \\
\hline Sweden & $-0.30(0.17)^{\dagger}$ & $0.08(0.15)$ \\
\hline Switzerland & $-0.11(0.25)$ & $-0.52(0.24)^{*}$ \\
\hline United Kingdom & $-0.49(0.21)^{*}$ & $0.04(0.19)$ \\
\hline Hungary & $-1.12(0.49)^{*}$ & $0.35(0.41)$ \\
\hline France & $-0.07(0.25)$ & $0.06(0.23)$ \\
\hline Belgium & $-0.27(0.19)$ & $0.10(0.17)$ \\
\hline
\end{tabular}


Norway

Firm age

Quality management system

Firm size

Company in sole proprietorship

Environment as a competitive factor

Environmental management system index

Informing consumers (i)

Market research on green products (ii)

Eco-labelling (iii)

Constant
$-0.05(0.24)$

$0.24(0.15)$

$0.11(0.14)$

$0.03(0.02)$

$0.17(0.12)$

$0.49(0.13) * * *$

$0.01(0.02)$

$0.52(0.12) * * *$

$0.90(0.16)^{* *}$

$0.66(0.15)^{* *}$

$-1.90(0.34) * * *$
$-0.29(0.20)$

$-0.15(0.14)$

$0.05(0.13)$

$0.03(0.02)$

$0.12(0.11)$

$0.16(0.12)$

$0.09(0.02) * * *$

$0.13(0.12)$

$0.57(0.15) * * *$

$-0.06(0.14)$

$-0.42(0.29)$
Observations

Log likelihood

$\mathrm{R}_{\text {process innovation, product innovation }}$

Likelihood ratio test of no correlation

Test for joint significance (i) - (iii)
763

$-837.72$

$0.19 * *$

$8.24 * *$

$105.04 * * *$

${ }^{\mathrm{a}}$ Robust standard errors in parentheses; ${ }^{\dagger} \mathrm{p}<.10 ;{ }^{*} \mathrm{p}<.05 ; * * \mathrm{p}<.01 ; * * * \mathrm{p}<.001$ 
TABLE 3

Multinomial logit model of product and process innovation ${ }^{\mathrm{a}}$

\begin{tabular}{|c|c|c|}
\hline Type of environmental innovation & Product and Process & Either Product or Process \\
\hline Food and tobacco & $0.17(0.39)$ & $-0.08(0.29)$ \\
\hline Textile products & $1.15(0.65)^{\dagger}$ & $0.75(0.49)$ \\
\hline Leather products & $0.66(1.03)$ & $-31.82(0.93) * * *$ \\
\hline Wood products & $0.20(0.55)$ & $-0.45(0.47)$ \\
\hline Pulp and paper products & $1.83(0.66)^{* *}$ & $1.19(0.56) *$ \\
\hline Publishing and printing & $0.64(0.48)$ & $-0.09(0.42)$ \\
\hline Energy, cokes and oil fuel & $-31.34(0.74) * * *$ & $-1.16(1.32)$ \\
\hline Chemical products and fibres & $1.24(0.43)^{* *}$ & $0.56(0.38)$ \\
\hline Rubber and plastics & $-0.41(0.48)$ & $-0.27(0.32)$ \\
\hline Non-ferrous mineral products & $0.79(0.65)$ & $0.31(0.55)$ \\
\hline Machines and equipment & $0.75(0.40)^{\dagger}$ & $0.12(0.32)$ \\
\hline Electrical and optical equipment & $0.84(0.43)^{\dagger}$ & $-0.06(0.39)$ \\
\hline Transport products & $0.44(0.65)$ & $-0.08(0.54)$ \\
\hline Other manufacturing & $0.50(0.36)$ & $-0.13(0.30)$ \\
\hline Germany & $1.10(0.37)^{* *}$ & $0.60(0.33)^{\dagger}$ \\
\hline Sweden & $-0.17(0.32)$ & $0.14(0.26)$ \\
\hline Switzerland & $-0.79(0.54)$ & $-0.32(0.39)$ \\
\hline United Kingdom & $-0.12(0.40)$ & $0.26(0.32)$ \\
\hline Hungary & $-1.04(0.94)$ & $0.37(0.66)$ \\
\hline France & $-0.22(0.54)$ & $0.37(0.39)$ \\
\hline Belgium & $-0.02(0.54)$ & $-0.09(0.30)$ \\
\hline
\end{tabular}




\begin{tabular}{|c|c|c|}
\hline Norway & $-0.49(0.43)$ & $-0.18(0.34)$ \\
\hline Firm age & $0.19(0.29)$ & $-0.13(0.24)$ \\
\hline Quality management system & $0.07(0.28)$ & $0.24(0.22)$ \\
\hline Firm size & $0.16(0.09)^{*}$ & $0.13(0.09)$ \\
\hline Company in sole proprietorship & $0.37(0.23)$ & $0.03(0.19)$ \\
\hline Environmental management & $0.22(0.04)^{* * *}$ & $0.09(0.03) * *$ \\
\hline \multicolumn{3}{|l|}{ system index } \\
\hline Environment as competitive factor & $1.26(0.24)^{* *}$ & $0.23(0.21)$ \\
\hline Constant & $-3.29(0.67)^{* *}$ & $-0.59(0.50)$ \\
\hline No. of observations & \multicolumn{2}{|r|}{849} \\
\hline Wald test & \multicolumn{2}{|r|}{$5669.81 * * *$} \\
\hline Log likelihood & \multicolumn{2}{|r|}{-812.77} \\
\hline Pseudo $\mathbf{R}^{2}$ & \multicolumn{2}{|r|}{0.11} \\
\hline
\end{tabular}

${ }^{a}$ Robust standard errors in parentheses; base category is "neither process nor product innovation";

${ }^{\dagger} \mathrm{p}<.10 ; * \mathrm{p}<.05 ; * * \mathrm{p}<.01 ; * * * \mathrm{p}<.001$ 


\section{TABLE 4}

Multinomial logit model of product and process innovation with managerial activity variables ${ }^{\mathrm{a}}$

\begin{tabular}{|c|c|c|}
\hline Type of environmental innovation & Product and Process & Either Product or Process \\
\hline Food and tobacco & $0.04(0.44)$ & $-0.18(0.31)$ \\
\hline Textile products & $0.87(0.72)$ & $0.44(0.50)$ \\
\hline Leather products & $0.69(0.96)$ & $-33.81(0.94)^{* * *}$ \\
\hline Wood products & $-0.73(0.59)$ & $-0.84(0.51)$ \\
\hline Pulp and paper products & $0.83(0.79)$ & $0.72(0.57)$ \\
\hline Publishing and printing & $0.15(0.62)$ & $-0.35(0.45)$ \\
\hline Energy, cokes and oil fuel & $-33.19(0.74)$ & $-1.17(1.20)$ \\
\hline Chemical products and fibres & $0.80(0.49)$ & $0.34(0.40)$ \\
\hline Rubber and plastics & $-0.41(0.50)$ & $-0.47(0.35)$ \\
\hline Non-ferrous mineral products & $0.91(0.69)$ & $0.18(0.61)$ \\
\hline Machines and equipment & $0.83(0.46)^{\dagger}$ & $0.12(0.33)$ \\
\hline Electrical and optical equipment & $0.53(0.54)$ & $-0.18(0.44)$ \\
\hline Transport products & $0.53(0.74)$ & $0.12(0.58)$ \\
\hline Other manufacturing & $0.67(0.40)$ & $-0.19(0.33)$ \\
\hline Germany & $0.84(0.43)^{*}$ & $0.60(0.35)^{\dagger}$ \\
\hline Sweden & $-0.33(0.37)$ & $-0.01(0.28)$ \\
\hline Switzerland & $-1.00(0.61)^{\dagger}$ & $-0.50(0.42)$ \\
\hline United Kingdom & $-0.73(0.46)$ & $0.13(0.33)$ \\
\hline Hungary & $-1.58(1.20)$ & $0.19(0.78)$ \\
\hline
\end{tabular}


France

Belgium

Norway

Firm age

Quality management system

Firm size

Company in sole proprietorship

Environmental management system index

Environment as a competitive factor

Eco-labelling (iii)

Informing consumers (i)

Market research on green products (ii)

Constant
$-0.29(0.61)$

$-0.23(0.41)$

$-0.52(0.50)$

$0.12(0.33)$

$0.10(0.32)$

$0.16(0.10)^{\dagger}$

$0.51(0.26)^{\dagger}$

$0.17(0.05)^{* * *}$

$0.95(0.28) * *$

$0.86(0.33)^{* * *}$

$0.98(0.27) * *$

$2.20(0.40)^{* *}$

$-3.45(0.79)^{* * * *}$
$0.28(0.41)$

$-0.12(0.32)$

$-0.42(0.37)$

$-0.16(0.26)$

$0.27(0.23)$

$0.13(0.10)$

$0.05(0.21)$

$0.07(0.03)^{*}$

$0.12(0.23)$

$0.25(0.28)$

$0.40(0.22)^{\dagger}$

$1.17(0.38)^{* *}$

$-0.52(0.54)$

\section{Observations}

Wald test

Log likelihood

Pseudo R ${ }^{2}$

Test for joint significance (i) - (iii)
762

$6693.89 * * *$

$-678.89$

0.17

\footnotetext{
a Robust standard errors in parentheses; base category is "neither process nor product innovation";

${ }^{\dagger} \mathrm{p}<.10 ; * \mathrm{p}<.05 ; * * \mathrm{p}<.01 ; * * * \mathrm{p}<.001$
} 